\title{
The Conceptual Mathematical Knowledge and Analytical Thinking for the First Stage Students at Math Sciences Department, Faculty of Education for Pure Sciences, IBN Alhaithem, University of Baghdad
}

\author{
Ban Hassan Majeed
}

\author{
Assistant Lecturer, faculty of Education for Pure Sciences, IBN Alhaithem, University of Baghdad
}

\begin{abstract}
The current research attempts to know the relationship between the mathematical knowledge of Conceptual and Analytical Thinking with the first phase of the students in the department of Mathematics Science, College of Education Pure Sciences / Ibn AlHaytham, University of Baghdad. The research sample consisted of (70) students distributors by (34) males \& (36) females. To measure the mathematical knowledge of Conceptual\& Analytical Thinking, the researcher built 2 tests, the first one to measure the mathematical knowledge of Conceptual\& the second to measure the Analytical Thinking. After data collection and analysis researcher found that the students have mathematical knowledge of Conceptual analogy premise average of the comparison has done, and they have analytical thinking compared to the average, which has by comparison, and there is a correlation between the mathematical knowledge of Conceptual and Analytical Thinking for students as a whole. In the light of these results, recommendations were made.
\end{abstract}

Keywords: Conceptual analogy, student

\section{Research Problem}

Modern mathematics focuses on mathematical ability, and looking at the mathematical content as knit building and communication, and basic building Unit are the concepts. Concepts are the most important forms of mathematical knowledge and the foundation upon which all other kinds of principles and laws and theories, which gained flexibility and help organize and digest. The concepts are more related to student life, if he realized student mathematical concepts and their meanings become meaningful mathematics and more clear and understandable. And help students to learn, and reduces the need for learning when faced with new situations and assists in the development strategies of thinking, and facilitates communication. It also helps to remember concepts and knowledge retention and retrieval (Darey, Terzinha, Peter * Christina, 2012).

And this is what makes learning concepts in priority learning math and education, one of the most important goals of mathematics teaching at all levels of education, and focus the attention of researchers and educators to develop math, this is confirmed by a document of the National Council of teachers of Mathematics (NCTM, 2000). The aim of our education is to develop processes of perception and comprehension which leads to strength of mathematics. Which means the student's ability to recognize relationships between mathematical knowledge (conceptual, procedural) and appear in hiring math concepts, and generalizations, and perceiving relationships and linkages between school mathematics and mathematics of life (at home, market, work.) and to understand the relationship between Mathematics and other disciplines. (Cantlon,1998:109)
Recalling (Katamey and others, 2000) that the method of thinking of anyone linked to the way in which receives knowledge, information and experiences, the way you arrange and organize this information, in the way that records and analyzes symbolizes and incorporating this information and kept in storage, and then get back up. The way you represent his way of expression as a means of physical sensory or semi-sham or symbolically, especially if he has a problem (Abu Akil, 2013:6) and analytical thinking is a style of thinking styles which individual educational material to hash a secondary or subsidiary elements. And recognize their relationships or links, which helps to understand their structure and work organization at a later stage (alaiasarh, 2011:190).

And the fact that the research process in analytical thinking and get comprehensive and holistic picture about is no less important than in other types of thinking, knowledge of analytical thinking, students can be productive in a society needs an infrastructure which in turn need to individuals able to configure mental perceptions Because their methods of solving problems and make the right decisions based on the facts. And as we live in an age of speed and technological revolutions highlights the need to prepare students to cope with social changes and accelerating society's scientific and technological change, and it comes through work on developing thinking skills, teaching thinking is providing students The tools that are needed to deal effectively with any kind of information or variables that come by tomorrow.

Analytical thinking skills and its relationship to cognitive structures perceptions of mathematics. Hence the search problem emerged as the determining conceptual mathematical knowledge at the first stage, students in the

Volume 6 Issue 12, December 2017 


\section{International Journal of Science and Research (IJSR) \\ ISSN (Online): 2319-7064}

Index Copernicus Value (2016): 79.57 | Impact Factor (2015): 6.391

Department of mathematics is the first step of many steps designed to improve students ' knowledge of mathematics in General and particularly conceptual, develop this knowledge which contributes to Better results, and how to exploit this knowledge and analytical thinking skills.

\section{The importance of research}

\subsection{Theoretical Importance}

1) The search provides a recent revision of the concept of mathematical knowledge, conceptual search results may provide a better understanding of the nature of the relationship of this variable analytical thinking among a sample of adult students in youth of college students, and also how he affected by other variables as a specialty and level of study.

2) The analytical thinking effective and important variable, because it enables students to acquire the ability to analyze and to thorough examination of ideas and attitudes through the broken sub components, and perceiving relationships or links between those components, so a clearer understanding of these situations, and work organization at a later stage.

\subsection{Practical Importance}

1) Stand over owning the first stage students math Sciences Department, College of Education Sciences/alhaithem of conceptual mathematical knowledge.

2) Identify the level of analytical thinking when college students.

3) Relational nature of the relationship between knowledge of mathematical knowledge of the conceptual and analytical thinking.

4) Tests of conceptual mathematical knowledge to specialists and researchers in mathematics, and also provide analytical thinking tests.

\subsection{Aim of Research}

1) Identify the conceptual mathematical knowledge. And also learn analytical thinking.

2) Determine the nature and direction of the relationship between conceptual mathematical knowledge and analytical thinking.

\subsection{Research Hypotheses}

Put zero hypothesis as follows:

1) There is no statistically significant difference at the level indication (0.05) between the average real performance and average performance this speculation when students first stage, Department of mathematics, College of Education Sciences/ahaitham, Baghdad University knowledge test The conceptual mathematical you prepared.

$$
\begin{aligned}
& \mathrm{H}_{0}: \overline{\mathrm{X}_{1}}=\overline{\mathrm{X}_{2}} \\
& \mathrm{H}_{1}: \overline{\mathrm{X}_{1}} \neq \overline{\mathrm{X}_{2}}
\end{aligned}
$$

2) There is no statistically significant difference at the level indication $(0.05)$ between the average real performance and average performance this speculation when students first stage, Department of mathematics, College of Education Sciences/alhazen, Baghdad University to test the analytical thinking give.

$$
\begin{aligned}
& \mathrm{H}_{0}: \overline{\mathrm{X}_{1}}=\overline{\mathrm{X}_{2}} \\
& \mathrm{H}_{1}: \overline{\mathrm{X}_{1}} \neq \overline{\mathrm{X}_{2}}
\end{aligned}
$$

3) There is a correlation between mathematical knowledge at the conceptual and analytical thinking denote (0.05) when students first stage, Department of mathematics, College of Education Sciences/alhaithem, University of Baghdad.

$$
\begin{aligned}
& \mathrm{H}_{0}: \overline{\mathrm{X}}_{1}=\overline{\mathrm{X}}_{2} \\
& \mathrm{H}_{1}: \overline{\mathrm{x}}_{1} \neq \overline{\mathrm{X}_{2}}
\end{aligned}
$$

\subsection{Research Limits}

1) First stage students (morning school), Department of mathematics, College of Education Sciences/ alhaithem, University of Baghdad.

2) The second semester of the year 2016-2017.

\subsection{Research Terms}

Mathematical Power: capacities of the student in understanding and employing mathematical knowledge in three dimensions (conceptual, procedural, problem) in the discovery and bonding and mathematical reasoning (NAEP, Knowledge: ' mental activity or mental representations as symbolic learning, problem solving, logic, and memory ' (Dunlosky * Metalfe, 2009:3). 2000:1-2).

Knowledge: ' mental activity or mental representations as symbolic learning, problem solving, logic, and memory ' (Dunlosky * Metalfe, 2009:3).

Mathematical knowledge: includes three types of knowledge and expertise: conceptual knowledge of procedural knowledge, problem solving and knowledge include the ability of the student to organize his thinking and cognitive and intellectual paths adjusted, plus experience Associated with problem solving (sweet, 2006:5).

Conceptual Knowledge: ability to learn mathematical concepts, read, write, rated, tagged, see multiple representations, and learn some concepts with relationship ' (his servants, 2007:57). And you know procedurally researcher for research purposes ' sample students ability to respond to paragraphs checksums for conceptual mathematical knowledge for the purposes of this research, measured by total grade obtained on this test.

Thinking: ' mental capacity linked to recognize logical relationships between the introductions and conclusions, and between the public and the similarities and differences, and different individuals in their ability to think because they use many thoughts at once ' (Ghanem Abu Awad, 2010:44).

Analytical Thinking: is the ability to compartmentalize educational material to secondary or subsidiary elements and understand their relationships or links, which helps to understand their structure and work organization at a later

\section{Volume 6 Issue 12, December 2017}




\section{International Journal of Science and Research (IJSR) \\ ISSN (Online): 2319-7064}

Index Copernicus Value (2016): 79.57 | Impact Factor (2015): 6.391

stage (GABARRE and Khalid, 2011:39). Thus you know procedurally researcher for research purposes ' sample students ability to respond to paragraphs checksums for analytical thinking for the purposes of this research, measured by total grade obtained on this test.

\section{Theoretical Background and Previous Studies}

The mathematical power: the national institution of educational progress (NAEP, 2003) indicates that the mathematical power student abilities describe mathematical knowledge, through three dimensions (conceptual knowledge, procedural knowledge, problem solving) in mathematical reasoning, And connect mathematical ideas and their interdependence in mathematical topics or in other areas. Mathematics force represents a major focus on mathematics education. It sees (Badawi, 2007:34) that no individual is strong athletes must be able to think and solve problems using mathematics, and build linkages within mathematics and between mathematics and other fields.

As well as referring (sweet, 2003:72) to force a public capacity mathematics expands beyond just mathematics abilities in cognitive understanding and procedural knowledge and problem solving to include pupils ' abilities to infer in mathematics situations communicate via cue and conclusions Can be derived from the mathematical context and coherence to nature in a situation with mathematical knowledge organization for life situations. The researcher agrees with the standards (NCTM, 2000) that the total interaction force is Mathematics operations capacity in light of content.

\section{Mathematical power components:}

\section{Mathematical power components}

Features by the possibility to specify three patterns for math is math communication, mathematical reasoning, and interdependence, as well as three levels of General Mathematics knowledge levels sub is conceptual knowledge, procedural knowledge, solving Problems (Alsaeed and Abdul Hamid, 2010:231). The mathematics power is the ability to use math and enjoyment, and give us a sense of control over our decisions and our environment if we understood enough mathematics will be used automatically and have greater control over ourselves and our society (Kenschaft, 1997).

An important aspect of the development of student mathematics power ability of mathematical reasoning, as reflected in the student's ability to view mathematics and life examples of concept and distinguished from non-examples, a conclusion also understood properties appear in some laws applied to cases connected with the conclusion Some new laws and associated with other cases, discover inaccuracies or errors in the mathematical operations or in solution of some problems, as well as appreciation and ensure results and reasonableness (Alsaeed and abdalhamid, 2010:250).

\section{Mathematical power development goals}

1) Understand the mathematical power language codes.
2) Understand conceptual construction components.

3) Understand the nature of mathematics and its significance.

4) Understand the importance of mathematics in life situations.

5) Concluded the system of mathematical rules and using them in situations and solve problems.

6) Check concept mathematics theme interdependence.

7) Maximum number of ideas within the mathematical position. (alsaeed, 2006:12).

\section{Knowledge}

Knowledge takes a number of styles depending on the nature of this knowledge as well as on ways and means used in acquisition and representation. Here are categorized (Yassin, 2007:78) knowledge: know what ad is known about the problem, and the distinction between right and wrong, and describe the different concepts and procedural knowledge associated with how to solve problems, beyond the knowledge that indicate characterization of knowledge itself, help in choosing The appropriate knowledge to solve the problem effectively through direct cognition methodology and thinking right direction and knowledge regarding the use of exploratory logic to set the process of thinking and perception.

And mathematics is considered as a cognitive areas, because they contribute to other knowledge areas. They are considered or science to provide any area of knowledge must be linked to a broad mathematical knowledge (Sood * Jitendra, 2007:150). Because of the rapid developments that have taken place in today's world and the many challenges, the most important education prepare learners capable of employing what he learned from aspects of learning to control his environment and control and using them in his service and serving his community, making attention to improve education quality and guaranteed On the one hand, and the relationship between the level and content of life experienced by the learner and his society meanwhile is critical. So it became necessary to prepare the individual to possess a variety of skills including:

1.hTe ability to employ the mathematical knowledge to face familiar and unfamiliar problems. 2. understand mathematics as a way of thinking more of being content includes a set of abstract concepts. (NCTM: 2000:4-5) and thus became the main target of mathematics education is to help the learner to understand the world and interact with it (slaves, 2004:25). Accordingly, the standard movement came in response to contemporary societal changes especially scientific, economic and technological changes is cultural society from schools nowadays that opportunities for learners to be mathematically educated and able to work an extension of what they learn in New attitudes, and also able to deal with an understanding with the age of technology.

National Council for teachers of Mathematics (NCTM: 2000:10) Emphasizes to contemporary trends in teaching and learning mathematics emphasizes the view of operations standards they represent important objectives we must all strive to achieve them behind mathematics education. These criteria related to processes that describe learning outcomes and represent the way to stretch and use knowledge and

\section{Volume 6 Issue 12, December 2017}




\section{International Journal of Science and Research (IJSR) \\ ISSN (Online): 2319-7064}

Index Copernicus Value (2016): 79.57 | Impact Factor (2015): 6.391

where process standards are performed by any mathematical content (Zaedan 2006:14).

\section{Mathematical knowledge}

Iit is a student's ability to identify and understand the role of mathematics to reach provisions based on sound foundations and the use of mathematics and dealt with to meet the student's needs as an active and responsible citizen life with good thinking (abogodh, 2009:22). And to learn mathematical knowledge in General helps students to adapt to the environment if within this learning to balance conceptual and procedural knowledge in particular.

Recalling (vine, 1999) that there are three abilities in mathematics is conceptual knowledge, procedural knowledge, problem solving.

1) Conceptual knowledge: it means the ability to learn mathematical concepts, read, write, rated, tagged, see multiple representations, and learn some concepts with relationship (his servants, 2007:57).

2) Procedural knowledge: it means the ability to make and implement algorithms and rules, laws and principles to the concepts and facts and circulars (his servants, 2007:58). 3. Problem solving: solving an important aspect considered in mathematics education and learning, but he's very math and robbed. And solving problems is more than just finding answers to rhetorical questions and exercises, where problem solving standard stipulates that all students ' construction of new mathematics knowledge through solving the issue is evident here solving problems is a way to learn mathematics (nctm, 2000:182-183).

So knowledge of basic math and skill in the use of the main requirements for the ordinary citizen who feels the importance and necessity of mathematics in his life, and have diverse processes and skill in mathematics such as four operations, and knowledge spaces, and sizes and amounts, dimensions And others, of great importance in daily life of mathematics inherent depth of natural phenomena (Secretary: 2001:164-165).

\section{Conceptual knowledge}

Conceptual knowledge is a mathematical abilities, and a component of mathematical abilities in strength mathematics, and suggests underlying structural relations mathematical ideas, linking it to explain and give meaning to action mathematics (miqdadi, 2013:1559). Containing the basic concepts of domain and overlapping one another meaning ' with science. ', Has been using several different structures, including semantic correlations and hierarchical and mental models (Byrnes * Wasik, 1999:777). In contrast to psychological research, it is relatively common in math education research see conceptual knowledge know and operate as quality. To summarize and display of conceptual knowledge where to focus on characteristics of knowledge seems commonplace in math education and research are closely linked to the question about how I should know to enhance students understanding is a key issue in the field of mathematics education (Star, Jon R., Stylianids J. 2013:16, Gabriel *).
Conceptual knowledge include relationships that make parts of all mathematical knowledge of facts and generalizations and principles and mathematical laws and regulations linked to a network of relevant links (Groth* Bergner, 2006:50). It also includes modeling concepts and their translation into semantics and mathematical system interprets ideas by using symbols and sentences and relationships needed to communicate.

Perceiving also include integration and interdependence between the main concepts, principles, laws and rules associated with mathematical concepts and interpretation of existing relations between them (Zulnaidi and Zakaria, 2010:27).

\section{Thinking}

The higher cognitive thinking is mental processes, as it's the most important aspects of mental activity. It is an interactive system of differential cognitive processes amenable to observation, measurement and training and development. Is the process through which new mental representation consists of information, be it by turning the information the complex interaction between mental activities which includes judgment and reasoning and problem solving (Alsaed, 2003:91). It takes multiple forms of thinking: thinking about converging and spaced, critical thinking, creative thinking, reflective thinking, analytical thinking (Samurai et al, 1994:169).

And he sees (Osman and Abu Hatab, 1978:225-268) to think six patterns:

1) Free dilapidation (fluency)

2) Restricted dilapidation (flexibility).

3) Intuitive thinking.

4) Depended thinking.

5) Innovative thinking.

6) Critical thinking.

\section{Thinking levels}

Some researchers identified thinking levels as follows:

1) Basic thinking: mental or intellectual non-complex activities that require exercise or enforce minimum three levels of Bloom's taxonomy of the cognitive domain or Conservation levels of mental comprehension and application, with few other skills like observation, comparison and classification, are skills to be perfected before moving to the level of thinking.

2) Thinking about the boat: represents a collection of complex mental processes that include critical thinking skills and creative thinking, problem solving, decision making and thinking over knowledge. (Saadah, 2006:60).

\section{Thinking skills}

1) Basic thinking skills: such as remembrance, observation, classification and comparison.

2) Higher thinking skills such as problem solving, decision making, creative thinking, critical thinking. We note that the basic thinking skills such as language character, and higher thinking skills such as words, and without the letters do not produce words. (alshumari, 2009:95). 


\section{International Journal of Science and Research (IJSR) \\ ISSN (Online): 2319-7064}

Index Copernicus Value (2016): 79.57 | Impact Factor (2015): 6.391

\section{Analytical thinking}

During the current time of scientific unlimited developments and technological discoveries, in the midst of a vast amount of problems as a result of massive pollution thinking has become imperative in order to overcome these problems. So there must be the capacity and skills of human at different analytical reflexology website or its level being able to resolve outstanding problems, accordingly referred (Ossimitz, 2003:77) he started thinking and attention to teaching thinking in many States, through several platforms is that thinking skill, any That way you learn a lot and working method. And learn to think he knows intelligence. And the wealth of minds is the real wealth of the nation. Smart nation is a nation that think and analyze, as the creators were faster advanced and sophisticated.

Tarman (2005, 20) describes analytical thinking as an individual's ability to analyze details of the situation into precise, detailed parts to find the right solution to the problem. The most basic definition of the problem is the ability to perform certain tasks that develop through interaction between genetic factors and environmental expertise, ie the ability of an individual to perform an activity, whether it is mental or mental, whether through availability or education or innate factors, such as the ability to solve mathematical problems, and the ability to analyze is the mental ability that enables the individual to scrutinize the ideas and attitudes (Amer, 2007).
Analytical thinking follows a sequential approach in steps and a scientific methodological curve. It follows each step until it reaches the desired goal and follows the more familiar and familiar path. Thinking and processes need a quiet environment to be creative, where analysis is in the process of disassociation(Inference, analysis, comparison, in-kind definition, abstraction, and generalization). And that analytical thinking occupies a stage of scientific thinking and decision-making stages (problem formulation, hypotheses, data collection, analysis, interpretation and understanding of their implications).. And that the process of analytical thinking is the common denominator of more than one process of thinking (Abu Bakil, 2013 5)..

\section{Analytical Thinking as a Mental Process}

The mental process within psychology is intended as a series of activities directed towards a particular goal, or a series of changes that take a particular form (Abd al-Hamid, 1987, 121). If we look at analytical thinking from this angle,we find that it represents one of the basic stages or steps related to a number of more complex thought processes such as coordination thinking, critical thinking, problem solving, decision making, scientific thinking, and creative solution to problems (Amer, 2007). As shown in Fig.1

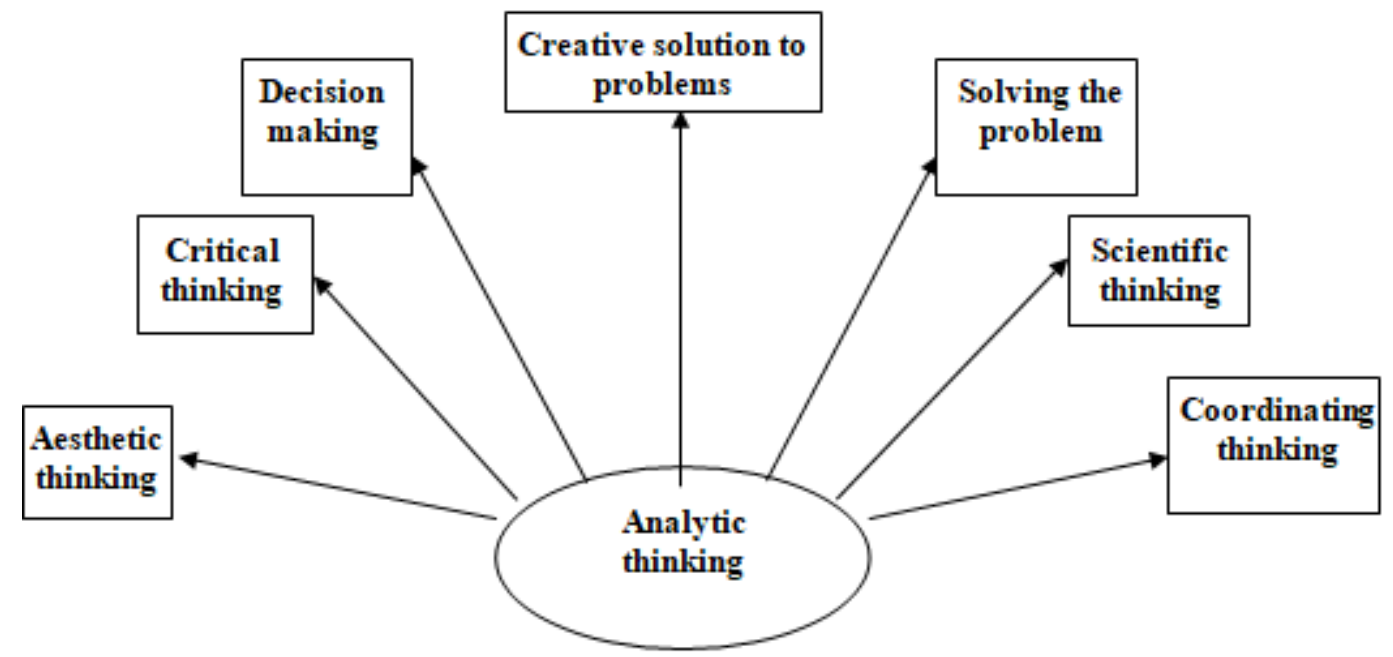

Figure 1: Analytical thinking is the common root of many other thinking processes

\section{Analytical Thinking Skills}

Analytical thinking skills have been defined as the ability to identify an idea or problem, analyze it into its components, organize information for decision-making, build a standard for evaluation and make appropriate conclusions. The most important analytical thinking skills are

1) Identifying attributes or attributes The ability to define the general features of objects, or the ability to devise an inclusive description.

2) Characterization Ability to identify the name, title or common features and attributes of objects and objects.

3) The relationship of the part to the whole relationship of things and their components. In the sense of knowing the small parts that are all, and then know what happens to all if not found this part of him and know his job for all.

4) Observation The ability to select appropriate properties, tools and procedures that guide and assist in the collection of information.

5) Arranging accidents, paragraphs, objects or contents in an organized and precise manner, or it means placing objects with a specific organization chosen very carefully.

6) Distinguish between different and different ability to identify similarities and differences between some topics or ideas

7) Comparison and interview ability to compare two or two people or two or more ideas from several angles and see what is in one of them and missing in the other. 


\section{International Journal of Science and Research (IJSR) \\ ISSN (Online): 2319-7064}

Index Copernicus Value (2016): 79.57 | Impact Factor (2015): 6.391

8) Classification The ability to classify information, organize it and put it into groups, ie, grouping objects or similar elements in a total Based on attributes or basic properties that were previously built.

9) Build a standard Identify and evaluate the most useful criteria that can be used to assess elements or items of importance, in order to reach certain provisions.

10) Arranging, prioritizing, and sequencing The ability to place items or events in sequence based on the quality values or order of objects or ideas according to a particular order, sequence types, alphabetical order, chronological order, or by interest in a particular area or by the value of the object.

11) Seeing the comparative relationships between ideas and events to determine the system between two or more processes.

12) Finding patterns Ability to recognize the special differences between two or more of thecharacteristics in a relationship that leads to a duplicate pattern.

13) Guessing / predicting / predicting the ability to use prior knowledge, comparison, or variance, specific relationships in identifying or anticipating similar events in the future, or using previous knowledge to add meaning to new information.

14) Determine the cause and effect, ie the ability to identify the causes or results of the largest and most powerful, for actions and events.

15) Measure procedure Identify relationships between familiar items or familiar events, and similar items and events in a new situation for the purpose of solving a problem or creative production.

16) The circular is used to construct a set of phrases and sentences that derive from the relationships between the relevant concepts or to construct sentences or phrases that can be applied in most or all circumstances, if not all, of them. (Hassan, 2010 150).

\section{Analytical thinking and its relationship to certain thought patterns}

The analytical thinking has related to structural and compositional thinking types if the analysis process enables us to compartmentalize what partial is complex, it is complex to what is simple both reconstruction and installation of parts lead to contrary combines only Chakkal separated to form more complex compounds. Analytical thinking relationship coordinating thinking, the most important characteristic of coordinating thinking is dependent on both the analytical thinking and compositional thinking and combine them together and thus link to one another to a large extent, how they slept together coherently if we seek complete bye position or The problem, called ability analysis and synthesis practice together with the ability to think of coordination. For analytical thinking relationship critical thinking, most researchers find clear differences between cash and not follow him analysis that follow him. The analysis seeks to break up ideas into their parts without passing judgment over the priority of any part, while cares about critical thinking to make a judgement on the quality of ideas after differentiation between them and choose the best. Analytical thinking relationship types of creative thinking is that creative thinking through bifurcation of thinking during the search for a solution to a problem, while another thinking type collects funeral put ideas and choose the best one to be the center of attention, in the light of this distinction is A critical thinking (Kazem, 2015:321).

\section{Behavior of students when using analytical thinking skills}

The first behavior determines the idea or problem with its components.

The second behavior examines and organizes information and identifies priorities.

The third behavior builds a standard and makes suggestions for a solution.

The fourth behavior applies solutions and performs them. (Hassan, 2010:188).

\section{Previous Studies}

These are some of the studies that have been found through the study of literature and scientific journals and research on international networks (Internet), which dealt with mathematical knowledge of conceptual and analytical thinking, and will be referred to in chronological order:

\begin{tabular}{|c|c|c|c|c|c|c|c|c|}
\hline Results & $\begin{array}{c}\text { Statistical } \\
\text { means }\end{array}$ & $\begin{array}{c}\text { Independent and } \\
\text { dependent } \\
\text { variable } \\
\end{array}$ & $\begin{array}{c}\text { Type of } \\
\text { curriculum }\end{array}$ & $\begin{array}{c}\text { Sample } \\
\text { size }\end{array}$ & subject & $\begin{array}{c}\begin{array}{c}\text { Students } \\
\text { gender }\end{array} \\
\end{array}$ & \begin{tabular}{|c|}
$\begin{array}{c}\text { Educational } \\
\text { level }\end{array}$ \\
\end{tabular} & $\begin{array}{l}\text { Researcher } \\
\text { name and } \\
\text { country }\end{array}$ \\
\hline $\begin{array}{l}\text { The low arithmetic } \\
\text { average of their } \\
\text { conceptual and } \\
\text { procedural knowledge. } \\
\text { There are statistically } \\
\text { significant differences } \\
\text { between the average } \\
\text { performance of students } \\
\text { on the test of conceptual } \\
\text { knowledge and the } \\
\text { average performance on } \\
\text { the test of procedural } \\
\text { knowledge in favor of } \\
\text { procedural knowledge. }\end{array}$ & $\begin{array}{c}\text { The mean, } \\
\text { standard } \\
\text { deviation, t-test } \\
\text { and correlation } \\
\text { coefficient }\end{array}$ & & descriptive & 105 & mathematics & male & $\begin{array}{l}\text { Classroom } \\
\text { Students } \\
\text { (Students } \\
\text { Applied) }\end{array}$ & $\begin{array}{l}\text { Makdadi et al., } \\
\text { 2013,Jordan }\end{array}$ \\
\hline $\begin{array}{l}\text { There was no statistically } \\
\text { significant difference at } \\
(0.05) \text { between the two } \\
\text { averages. The calculated }\end{array}$ & $\begin{array}{c}\text { To examine the } \\
\text { hypotheses, use } \\
\text { the analysis of } \\
\text { the common }\end{array}$ & $\begin{array}{c}\text { Independent } \\
\text { teaching in } \\
\text { accordance with } \\
\text { mathematical } \\
\end{array}$ & $\begin{array}{c}\text { Semi } \\
\text { experimental }\end{array}$ & 60 & mathematics & fe male & $8^{\text {th }}$ primary & $\begin{array}{l}\text { Alkubailat and } \\
\text { Ahmed, 2013, } \\
\text { Jordan }\end{array}$ \\
\hline
\end{tabular}

Volume 6 Issue 12, December 2017 
International Journal of Science and Research (IJSR)

ISSN (Online): 2319-7064

Index Copernicus Value (2016): 79.57 | Impact Factor (2015): 6.391

\begin{tabular}{|c|c|c|c|c|c|c|c|}
\hline \begin{tabular}{|} 
calculations of the \\
conceptual \\
comprehension levels of \\
the students were due to \\
the teaching method, but \\
there was a difference of \\
statistical significance at \\
(0.05) Among the \\
averages, the two \\
computations for the \\
degrees of the analysis \\
and composition \\
component of the \\
conceptual \\
comprehension are \\
attributed to the teaching \\
method and to the \\
teaching according to the \\
mathematical strength.
\end{tabular} & $\begin{array}{c}\text { mono-variance } \\
\text { and the analysis } \\
\text { of the common } \\
\text { multiple } \\
\text { variance }\end{array}$ & $\begin{array}{c}\text { strength and } \\
\text { understanding of } \\
\text { mathematical } \\
\text { concepts. }\end{array}$ & & & & & \\
\hline \begin{tabular}{|c|} 
That the students of the \\
experimental group have \\
developed the skills and \\
skills of analytical \\
thinking, and that \\
mathematics in general \\
works to develop \\
analytical thinking. And \\
that students generally \\
lack analytical reasoning \\
abilities. \\
\end{tabular} & & $\begin{array}{c}\text { students possess } \\
\text { the capabilities of } \\
\text { analytical thinking } \\
\text { and their } \\
\text { orientation toward } \\
\text { mathematics }\end{array}$ & experimental & 38 & mathematics & male & $\begin{array}{l}\text { Renuwat,2009, } \\
\text { Thailand }\end{array}$ \\
\hline
\end{tabular}

\section{Research Methodology}

1) The research method is based on analytical descriptive research. It seeks to collect descriptive data on the relationship between mathematical knowledge and analytical thinking, then analysis, linking and interpretation of these data and drawing conclusions.

2) The research community includes the Department of Mathematics Sciences, College of Education for Pure Sciences / Ibn Al-Haytham, University of Baghdad for the academic year 2016-2017.

3) Sample Research The sample of the research (70) students from the first phase students (morning study). 4. Search tools for the purpose of answering questions

\footnotetext{
Preparation of the test of conceptual mathematical knowledge

In light of what was presented from the theoretical background and the definition of the terms included in the title of the research. For the purpose of formulating the terms of the test of mathematical knowledge, a number of tests related to mathematics strength were examined. The researcher was not able to see specific tests to measure this concept in mathematics directly because all the studies and research that dealt with this concept dealt with by measures determined within the concept of mathematical strength. A test was built to measure mathematical knowledge for the students.also test to measure the level of analytical thinking they have.
}

Steps to build the test of conceptual mathematical knowledge
1) Define the concept of mathematical knowledge, where the dimensions of the test is defined as (communication in the language of mathematics

2) Mathematical interdependence

3) Mathematical reasoning

4) Mathematical representations) at the level of mathematical knowledge.

\section{Steps to Build the Analytical Thinking Test}

1) Determine the concept of analytical thinking, where the dimensions of the test are defined so that all analytical thinking skills are defined.

2) Identify its areas and submit them to experts.

3) Formulation of test paragraphs in light areas, and prepare test instructions and clarity of the paragraphs.

4) Correcting the test paragraphs and conducting statistical analysis.

5) Confirm the psychometric properties of the test.

The final application on the research sample

For the purpose of answering the research questions and verifying its hypotheses, and after conducting the appropriate statistical treatments for both the test of conceptual mathematical knowledge and the test of analytical thinking. The application shall be carried out under appropriate environmental conditions The data were therefore ready for statistical analysis purposes.

\section{Presentation and interpretation of results related to conceptual mathematical knowledge.}


International Journal of Science and Research (IJSR)

ISSN (Online): 2319-7064

Index Copernicus Value (2016): 79.57 | Impact Factor (2015): 6.391

Table 1

\begin{tabular}{|c|c|c|c|c|c|c|c|}
\hline $\begin{array}{c}\text { Freedom } \\
\text { degree }\end{array}$ & $\begin{array}{c}\text { Significant } \\
\text { Level }\end{array}$ & Tabular t value & $\begin{array}{c}\text { Calculated } \\
\text { t value }\end{array}$ & $\begin{array}{c}\text { Supposed } \\
\text { mean }\end{array}$ & $\begin{array}{c}\text { Error } \\
\text { deviation }\end{array}$ & $\begin{array}{c}\text { Standard } \\
\text { deviation }\end{array}$ & $\begin{array}{c}\text { Arithmetic } \\
\text { mean }\end{array}$ \\
\hline 69 & 0.05 & 1.997 & 25.252 & 40 & 0.879 & 7.360 & 62.214 \\
\hline
\end{tabular}

From the observation of the above table and compare the arithmetic mean of the scores obtained by the sample students on the test of measuring the mathematical knowledge of the conceptual with the mean average where it was higher. Therefore, the differences are in favor of the arithmetic mean, ie, the sample students have the knowledge of mathematical concepts that represent a component of mathematical knowledge. And to test the validity of the zero hypothesis' there is no significant difference at the level of significance $(0.05)$ between the average real performance and the average performance of the students of the first stage, the Department of Mathematics Sciences, College of Education for Pure Sciences / Ibn al-Haytham, Baghdad University on the test of knowledge irrigation and to test the validity of the zero hypothesis' there is no significant difference at the level of significance $(0.05)$ between the average real performance and the average performance of the students of the first stage, the Department of Mathematics Sciences, College of Education for Pure Sciences / Ibn al-Haytham, Baghdad University on the test of knowledge irrigation At the level of significance (0.05) between the average performance of the students and the average performance satisfactory (40) on the test of mathematical knowledge and conceptual, and this supports the conclusion in the above, namely the possession of sample students of conceptual mathematical knowledge.

\section{Results related to the correlative relationship}

Between mathematical knowledge and analytical thinking. The following null hypothesis was tested: 'There is no correlation between mathematical knowledge and analytical thinking at the level of significance (0.05) for the students of the first stage, the Department of Mathematics, College of Education for Pure Sciences / Ibn Al-Haytham, University of Baghdad on the tests prepared for this purpose '. Pearson correlation coefficient was used to calculate the coefficient of correlation between students' scores on the test conceptual mathematical knowledge and their degrees on the test of analytical thinking. To measure correlation significance, the t-test of correlation coefficients was used to test the validity of the previous hypothesis, and the results were as shown below.

Table 3: (correlation coefficients between conceptual mathematical knowledge and analytical thinking and correlation significance in the research sample)

\begin{tabular}{|c|c|c|c|c|c|}
\hline Significant level & Freedom degree & Tabular T value & Calculated t value & Coefficient factor & relationship \\
\hline 0.05 & 68 & 1.997 & 6.266 & 0.605 & $\begin{array}{c}\text { Mathematical conceptual } \\
\text { knowledge with analytical } \\
\text { thinking }\end{array}$ \\
\hline
\end{tabular}

The coefficient of correlation between the mathematical knowledge and the analytical thinking of the sample scores was 0.605 . This is a positive correlation coefficient, because the values of the correlation coefficients are between $-1,1$ and the closer they are to (1) the stronger the coefficients. And the calculated $\mathrm{T}$ value.

The calculated $\mathrm{T}$ value is greater than the tabular value at the significance level (0.05), indicating the rejection of the previous zero hypothesis for mathematical knowledge and its relation to analytical thinking, that is, there is a strong positive correlation between the two variables, This is logical because anyone who has a good performance with mathematical knowledge has the ability to understand facts, generalizations, principles, rules and mathematical rules and the ability to control them, and whoever possesses all of that, is certainly an analytical thinker and can deal with him and with all his skills because he has a knowledge base that enables him to do so.

\section{Conclusions}

1) Acquisition of students of the first stage Department of Mathematics Sciences, College of Education for Pure Sciences / Ibn al-Haytham, University of Baghdad, the mathematical knowledge of the conceptual compared to the average mean that was compared.

2) They also have analytical thinking.
3) There is a correlation between the mathematical knowledge of conceptual and analytical thinking of the students as a whole.

\section{Recommendations}

1) The focus of teachers on the employment of conceptual knowledge in the teaching of mathematics, and the formation of a deep conceptual structure to gain the ability to apply mathematical processes in good ways.

2) Use of effective educational strategies to improve the conceptual structure of mathematics in students, through which to focus on conceptual knowledge and link with procedural knowledge to be a comprehensive treatment.

3) Developing the analytical thinking abilities of college students, especially the faculties of scientific specialization, and motivating them to sound mathematical thinking that is far from conservation and indoctrination, and is working to stimulate their higher thinking levels and employ scientific knowledge to keep abreast of scientific progress and the spirit of the times.

\section{Proposals}

1) Conduct a similar study on the same stage in the Department of Computers, and compare their results with current search results. 


\section{International Journal of Science and Research (IJSR) \\ ISSN (Online): 2319-7064}

Index Copernicus Value (2016): 79.57 | Impact Factor (2015): 6.391

2) Conduct a similar study on the other stages in the Mathematics Department. And conducting a similar study on the same stages in the Department of Computers. And then conducting a comparative study among students. And then a comparative study between the students of the department of computers and students of the Department of Mathematics at the Faculty of Education.

3) Conduct a study to find out the correlation between conceptual and procedural knowledge.

4) Conduct a study to find out the correlation between analytical thinking and creative thinking.

\section{References}

[1] Abu Joudeh, Somma, (2009) Role of Curricula and Teachers in the Behavior of the Road to 21st Century Skills, American University, Department of Education, Beirut.

[2] Abu Aqil, Ibrahim (2013) The level of analytical thinking in solving problems in Hebron University students and its relation to some variables, Hebron University Journal of Research, Vol. Amin, Ismail

[3] Mohamed, (2001) Methods of teaching mathematics theories and applications, a series of references in education and psychology (17), Dar al-Fikr al-Arabi, Cairo. Badawi, Ramadan Massad, (2007) Teaching Effective Mathematics, Dar Al Fikr, Amman.

[4] Hassan, Jamil Hassan, (2010) for gifted and creative learning and learning strategies, Knowledge Knowledge, p (188). Retrieved from http: //www.almarefh.org/news.php?action show * id 4597.

[5] ALsaeed Ahmed Al-Bahi, (2003) Modeling the relations between the methods of thinking and the efficiency of the cognitive representation of information among undergraduate students, Egyptian Journal of Psychological Studies, vol. (13), p (39). His Excellency,

[6] Jawdat Ahmed, (2001) Formulation of educational objectives in all subjects The book of five thousand goals, Dar Al-Shorouk, Amman.

[7] Ryan, Mohamed Hashim, (2006) Teaching strategies for the development of thinking, Dar Haneen, Amman. Zidane, Abeer Ibrahim, (2006) Use Marzano's Thinking / Learning Dimensions Model to Achieve Some Operating Standards for Mathematics In the preparatory stage, unpublished doctoral thesis, Faculty of Education, Tanta University.

[8] Al Samarrai, Hashim et al., (1994) General Teaching Methods and Thinking Development, Dar al-Amal, Irbid. Al - Saeed, Reza Massaad and Abdul - Hamid Nasser Al - Sayed, (2010) Quality Assurance in Curriculum - Standards, Operations and Expected Outputs, University Education House, Alexandria.

[9] Al-Saeed, Reda Mosaad, (2003). Mathematical power: a modern approach to the development and evaluation of mathematics learning in the general education stages, the third scientific conference, teaching and learning mathematics and creativity development, the Egyptian Association of Mathematics Education, 8-9 October.Guest House, Ain Shams University.

[10] Saeed, Reza Massad, (2006) The levels of mathematical communication available to students in the ninth grade in light of the standards of the National Council of Teachers of Mathematics (NCTM), Sultan Qaboos University, Muscat. Al-Shammari, Fahd Abdul Rahman, (2009) Media Education, I, 1

[11] Al-Shammari, Fahad Abdul Rahman, (2009) Media Education, 1, Saudi Arabia. Amer, Ayman, (2007) analytical thinking ability, skill and style, i 1, Center for the development of graduate studies and research in engineering sciences, Cairo University, Egypt. At www.pathways@pathway.edu.eg .

[12] Abdul Hamid, Shaker, (1987) creative process in the art of photography, the world of knowledge, p (901), Kuwait. Obaid, William Taoudros, (2004) Teaching mathematics to all children in light of the requirements of standards and the culture of thinking, Dar AlMasirah, Amman.

[13] Obaidah, Nasser Al-Sayed Abdul Hamid, (2007 a) The development of the mathematics curriculum in the light of contemporary standards and the impact on the development of the power of mathematics in primary school students, unpublished doctoral thesis, Faculty of Education in Shebin Kom - University of Menoufia.

[14] Obaidah, Nasser Al-Sayed Abdul Hamid, (2007b) Development of some components of spatial sense and geometric reasoning using Origami among primary school students, research presented to the Seventh Scientific Conference, Egyptian Society of Mathematics Mathematics, Ain Shams University, Cairo.

[15] Othman, Sayed Ahmed and Abu Hatab, Fouad Abdel Latif, (1978) Thinking-Psychological Studies, I 2, The Anglo-Egyptian Library, Cairo. AlAyazra, Walid Rafiq, (2011) Strategies of teaching thinking and skills, Dar Osama, Amman.

[16] Ghanem, Bassam and Frial Abu Awad, (2010) The degree of prevalence of superstitious ideas among students of the faculties of educational sciences in Jordanian universities, published study, Al-Najah Research Journal (Humanities), (24).

[17] Ghubari, Thaer Ahmed, and Khalid Mohammed Abu Shurayh, (2011) Fundamentals of Thinking, i 1, 1, Arab Community Library, Amman. Qatami, Youssef et al., (2000) Design of Teaching, 1, Dar Al-Fikr, Amman.

[18] Karma, Munir Abdul Aziz, (1999) The Relationship between Numerical Sense and Mathematical Performance in Mathematics for Ninth Grade Students in Bethlehem District Schools, master Thesis, Birzeit University, Palestine. Kazem, Saad Saleh, (2015) Analytical Thinking among University Students, Diyala Journal, p (68).

[19] Makdadi, Ruba Mohamed Fakhri et al., (2013) Conceptual Knowledge and Procedural Knowledge of Fractures and Their Relation to Math Concerns among Students / Teachers, Studies, Educational Sciences, Vol. 40, p.

[20] Ministry of Higher Education, (2013) .The balance between procedural knowledge and conceptual knowledge and the factors affecting it among the mathematics teachers in the primary stage in Saudi Arabia, published study, Center of Research Excellence in the development of science and mathematics education.

\section{Volume 6 Issue 12, December 2017}




\section{International Journal of Science and Research (IJSR) \\ ISSN (Online): 2319-7064}

Index Copernicus Value (2016): 79.57 | Impact Factor (2015): 6.391

[21] Yasin, Saad, (2007) Knowledge Management, Systems and Techniques, Dar Al-Maajah, Amman.

[22] Byrnes, J. P., \& Wasik, B. A., (1999): Role of conceptual knowledge in mathematical procedural learning. Developmental Psychology, 5, 777-786. Cantlon, Danise, ( 2001): Kids + Conjecture =Mathematics Power..22

[23] Dareym, H., Terzinha, N., Peter, B. \& Christina, T., (2012): Individual Differences in Conceptual \& Procedural Fraction Understanding: The Role of Abilities \& School Experience. Journal of Experimental Child Psychology, 113 (4): 469-486.

[24] Dunlosky, J. \& Metcalfe, J., (2009): Meta cognition, Sage publications, Inc.

[25] Groth, R. \& Bergner, J., (2006): Preservice elementary teachers conceptual \& procedural knowledge of Mean,Median \& Mode. Mathematical Thinking \& Learning, 8 (1): 37-63.

[26] Kenschaft, Patricia Clark., (1997): MATH POWER "How to help your child love math even if you don't "An imprint of Pearson Education", Inc. 1185 Avenue of the Americas, New York, New York 10036.

[27] National Association of Education Progress (NEAP), ( 2003): Cognitive Abilities, Retrieved April 15, 2011, from: www.naep.org / publications / frameworks/ math.../ ch4.html.
[28] National Association of Educational Progress (NEAP), (2000): Cognitive Abilities.

[29] National Council of Teacher of Mathematics (NCTM), (2000): Principles and Standards for School Mathematics. Reston, VA: Author.

[30] Ossimitz, Gunter (2003): The Development Of Systems Thinking Skills Using System Dynamics Modeling Tools, Journal of Psychology, V(86), New York.

[31] Sood, S. \& Jitendra, A. (2007): A Comparative analysis of number sense instruction in reform based \& traditional mathematics textbooks. Journal of Special Education, 41 (3), 145-157.

[32] Star, J. R., (2002): Re-conceptualizing procedural knowledge: The emergence of "intelligent" performances among equation solvers. In $D$.

[33] Star, Jon R., \& Gabriel J. Stylianides., (2013): Procedural \& Conceptual Knowledge: Exploring the Gap Between Knowledge Type \& Knowledge Quality. Canadian Journal of Science, Mathematics, \& Technology Education 13, no.2:169-181.

[34] Zulnaidi, H. \& Zakaria, E., (2010): The effect of information mapping strategy on mathematics conceptual knowledge of junior highschool students. US-China Education Review, 7 (1): 26-31.

Supplements

(Supplement No.1)

\begin{tabular}{|c|c|c|}
\hline No. & The Name & Specialization \\
\hline 1 & P. Dr. Rafid Al-Mayouf & Methods of Teaching Mathematics \\
\hline 2 & P. Dr. Luma Naji Mohammed & Mathematics \\
\hline 3 & Assistant P. Dr. Laith Aiash & Educational psychology \\
\hline 4 & Assistant P. Dr. Munteha Mutasher & Educational psychology \\
\hline 5 & T. Dr. Areej Khadher Hassan & Methods of Teaching Mathematics \\
\hline 6 & T. Dr. Allaa Al-Deen Ali Hussain & Educational psychology \\
\hline 7 & T. Dr. Ghada Hassan Ibrahim & Applied mathematics \\
\hline
\end{tabular}

The Mathematical Knowledge of Conceptual Test

(Supplement No.2)

Q1/ Express the numerical scale of the real numbers.

Q2/ Draw graphically:

\begin{tabular}{|l|l|}
\hline$-5<x<0$ & \\
\hline$\|x\|<3$ & \\
\hline$x \geq 1$ & \\
\hline
\end{tabular}

Q3/ Translate concepts below using symbols:

\begin{tabular}{|l|l|}
\hline $\mathrm{x} €[\mathrm{a}, \mathrm{b}]$ & \\
\hline $\mathrm{x} €(\mathrm{a}, \mathrm{b}]$ & \\
\hline $\mathrm{x} €[\mathrm{a}, \mathrm{b})$ & \\
\hline
\end{tabular}

$Z=x^{\wedge} 2+3 x y+y^{\wedge} 2: Q 4 /$ Find all partial derivatives

dy/dx, Find $x=\sqrt{ } y+5 Q 5 /$ If

Q6/ Write Only three properties of integrations.

Q7/ Prove the validity of the relationship by means of mathematical induction:

$1 / 4 n^{\wedge} 2-1=n / 2 n+1$

$1 / 5=x-2) /(x+2)(Q 8$ :

Calculate

The Analytical Thinking Test(Supplement No.3)

Volume 6 Issue 12, December 2017 www.ijsr.net 
International Journal of Science and Research (IJSR)

ISSN (Online): 2319-7064

Index Copernicus Value (2016): 79.57 | Impact Factor (2015): 6.391

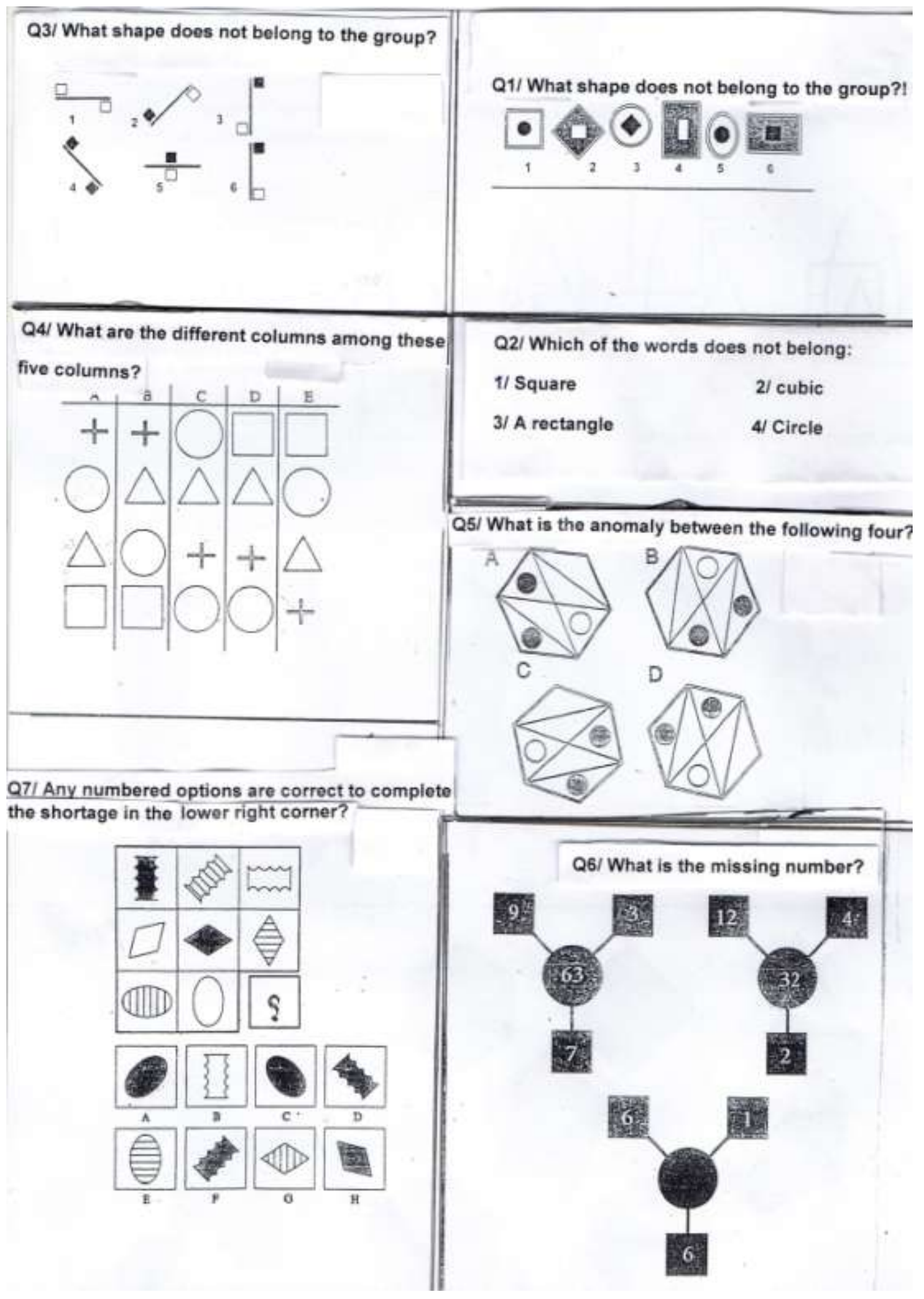

Volume 6 Issue 12, December 2017

www.ijsr.net

Licensed Under Creative Commons Attribution CC BY 
Q8/ In the picture we see four groups composed of overlapping geometric shapes, rectangle, triangle, square and oval, but one of them is a little odd. Can you find it?
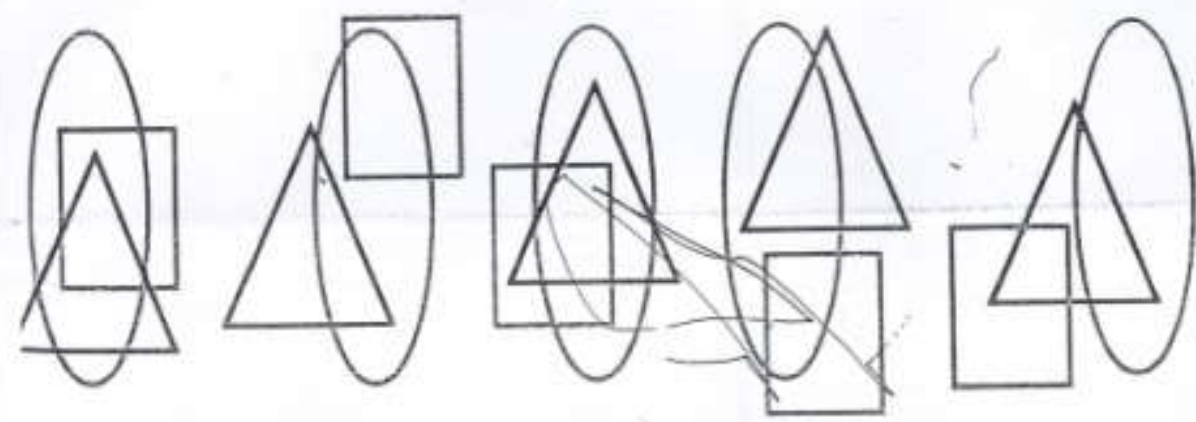

Q9/ Any of these shapes is different from the other four?
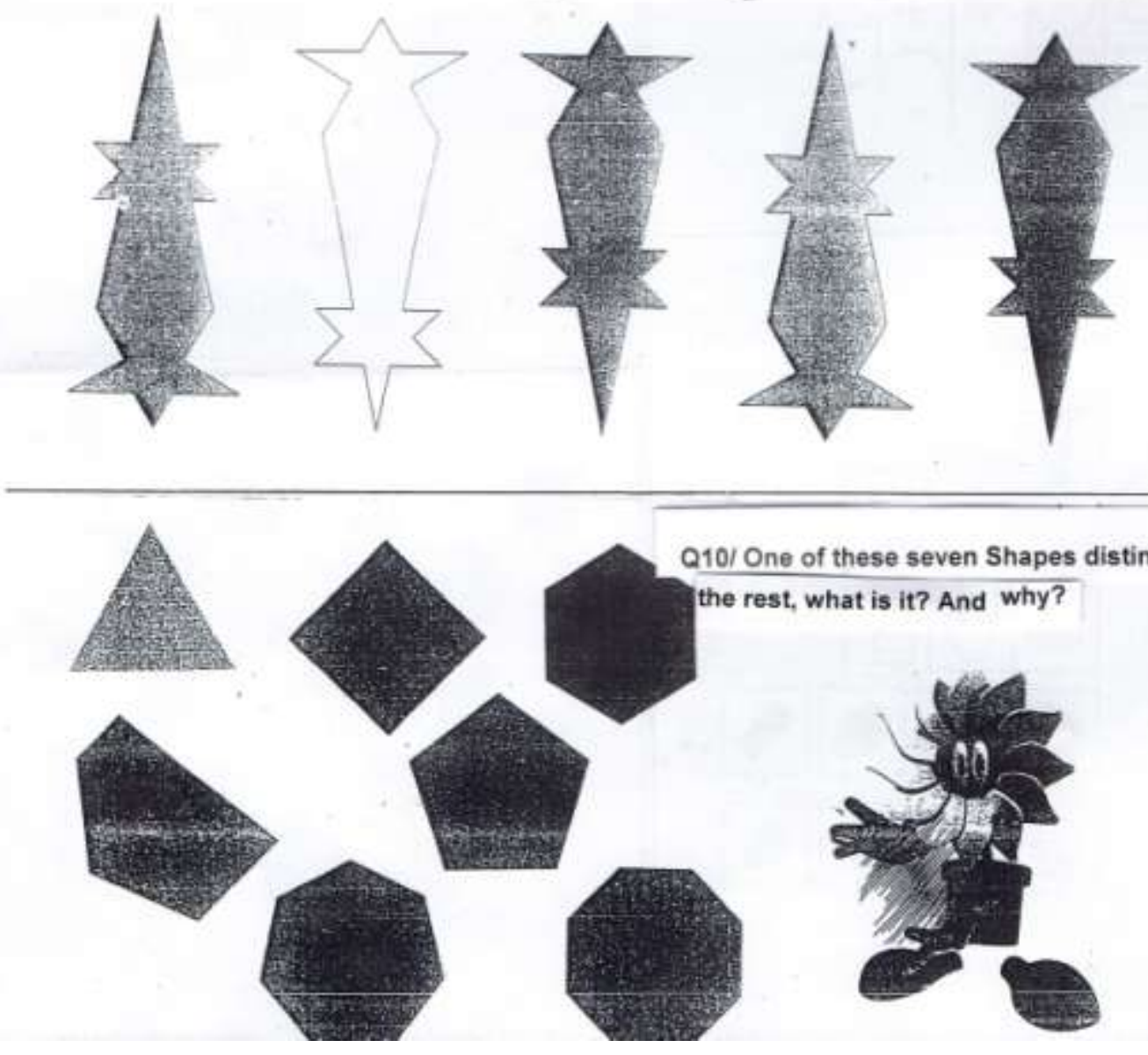

Q10/ One of these seven Shapes distinct from the rest, what is it? And why?

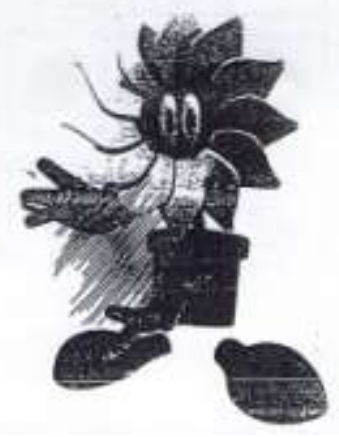

Volume 6 Issue 12, December 2017 www.ijsr.net

Licensed Under Creative Commons Attribution CC BY 
International Journal of Science and Research (IJSR)

ISSN (Online): 2319-7064

Index Copernicus Value (2016): 79.57 | Impact Factor (2015): 6.391

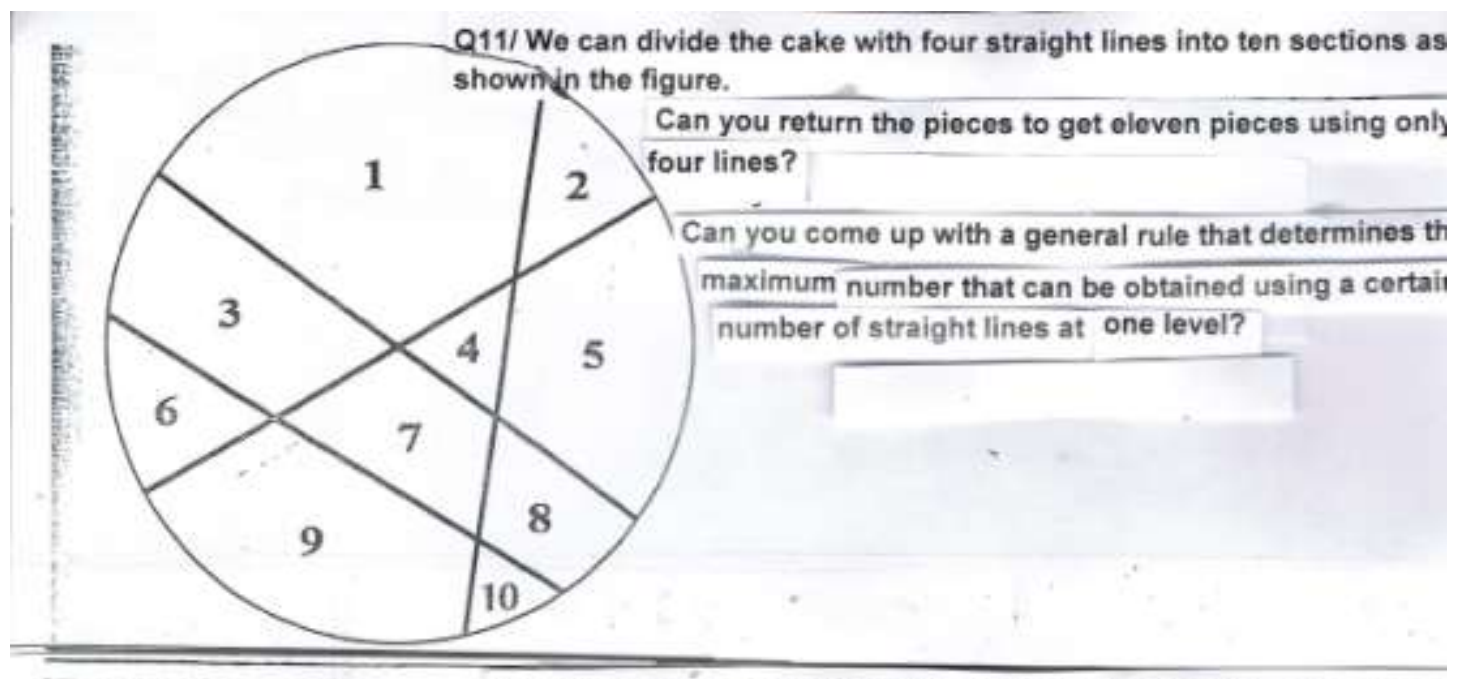

Q12/ This paintina has a fantastic feature, Can you guess what it is? You'll quickly discover that the total numbers in each row,

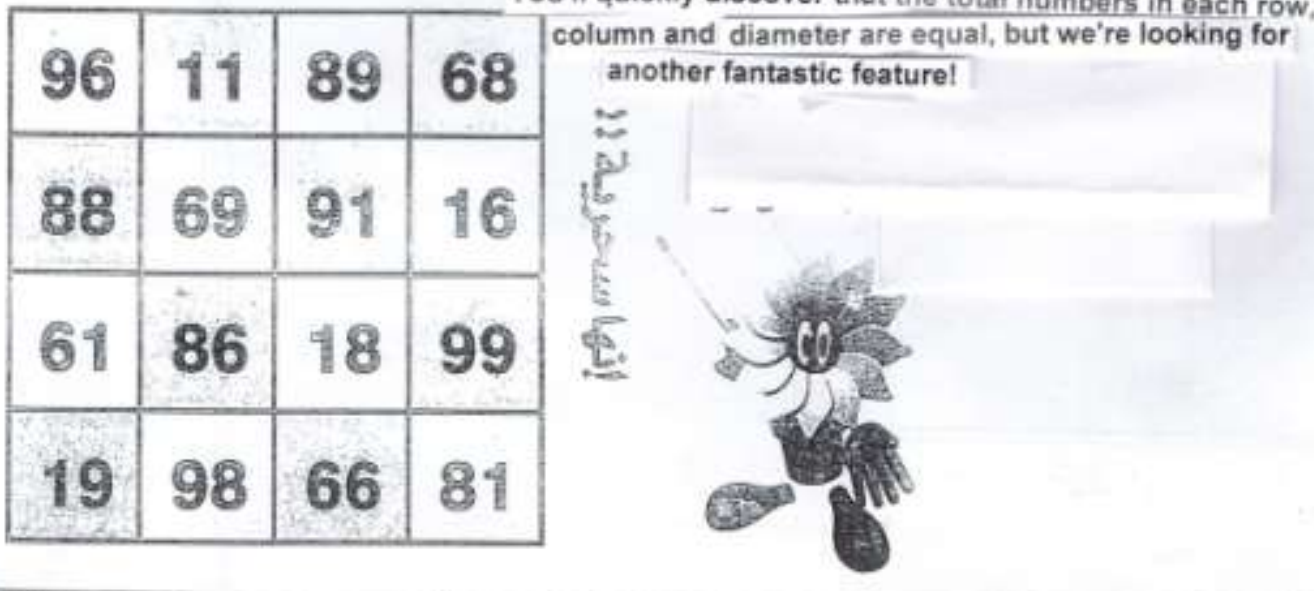

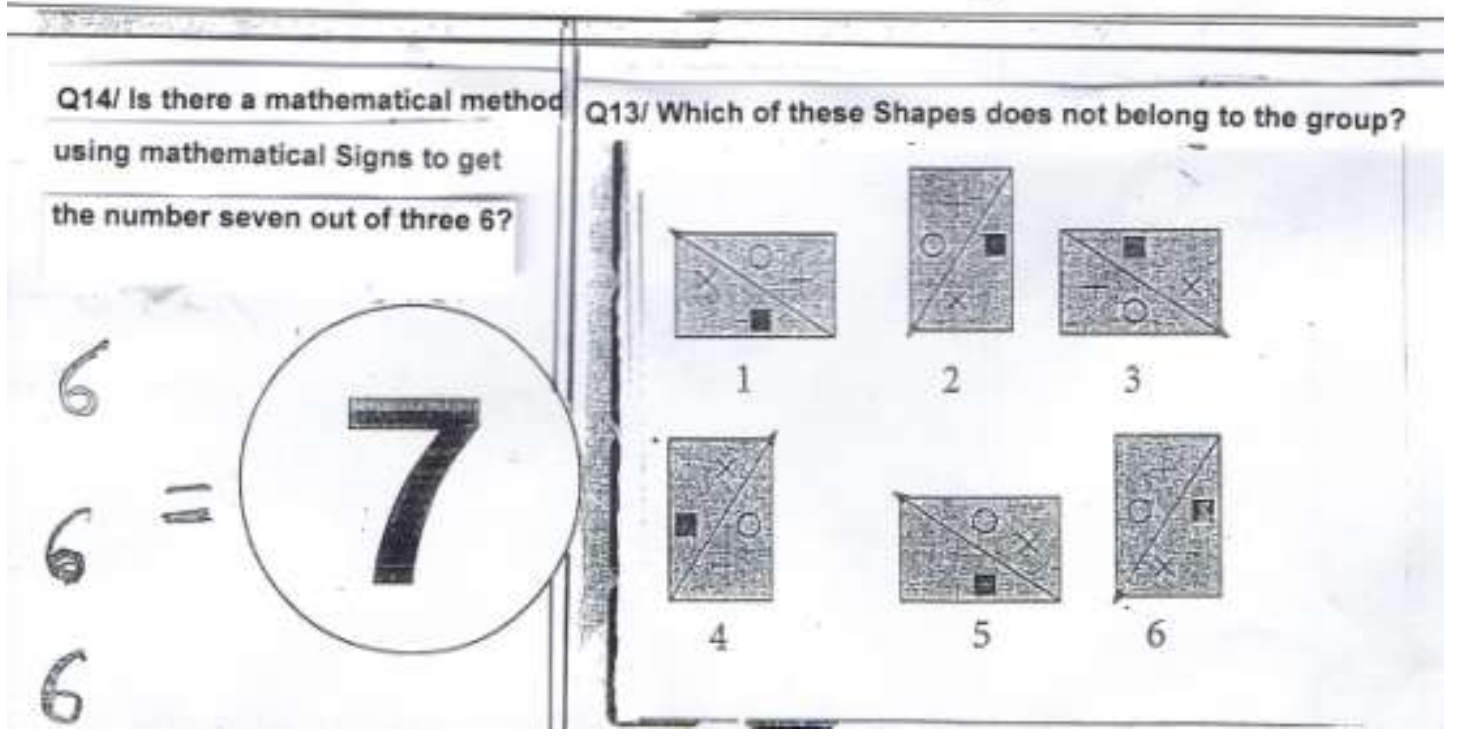

Volume 6 Issue 12, December 2017

www.ijsr.net

Licensed Under Creative Commons Attribution CC BY 


\section{International Journal of Science and Research (IJSR) \\ ISSN (Online): 2319-7064}

Index Copernicus Value (2016): 79.57 | Impact Factor (2015): 6.391

Q15/ Can you move only one number to a new position where the following equation becomes true? (Not allowed to move mathematical Signs)

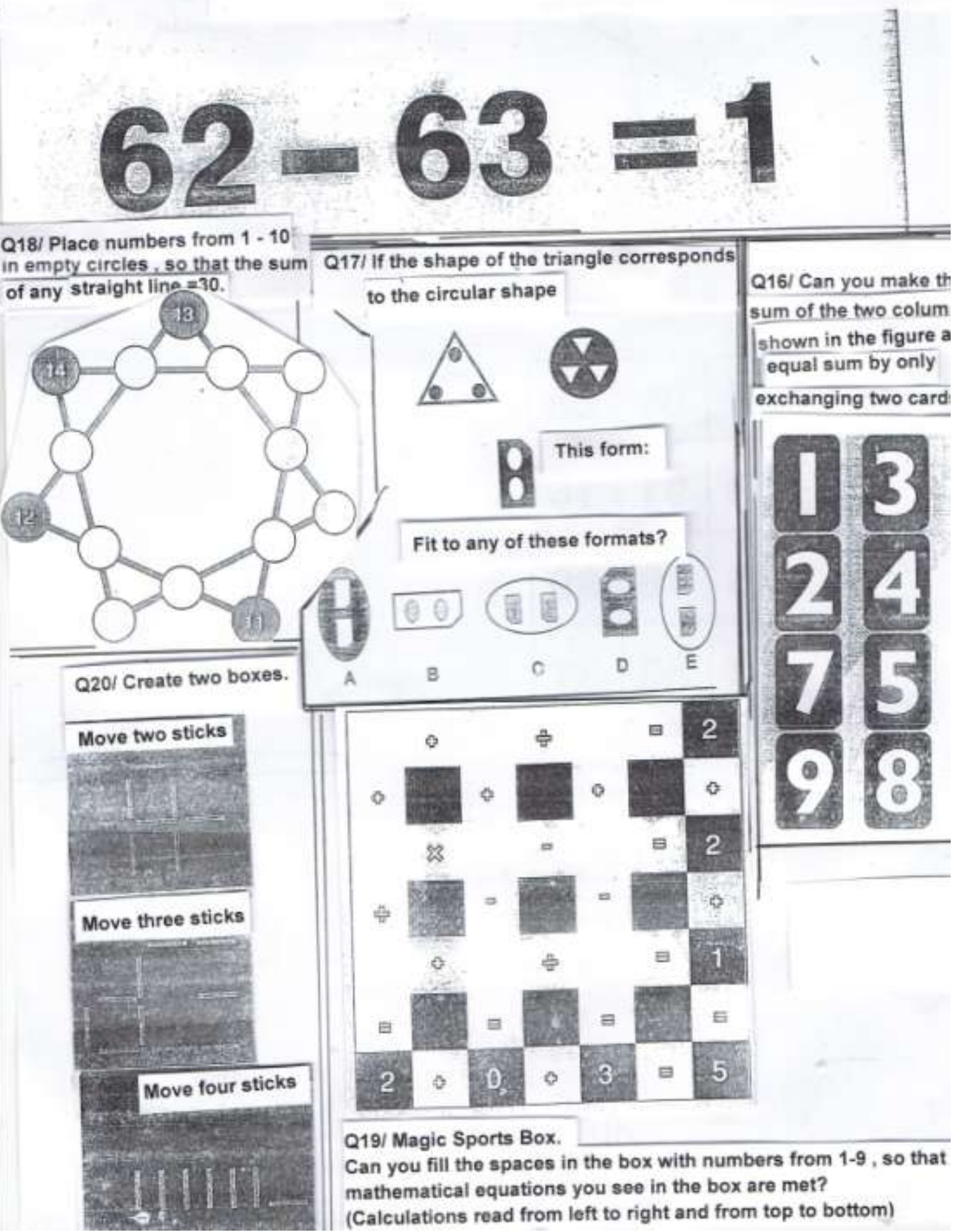

Volume 6 Issue 12, December 2017

www.ijsr.net

Licensed Under Creative Commons Attribution CC BY 